\title{
Chemical exposures at work in early pregnancy and congenital defect: a case-referent study
}

\author{
J C McDonald, J LAvoie, R Côté, A D McDonald \\ From the Institut de Recherche en Santé et en Sécurité du Travail du Québec, Montreal, Quebec H3A 3C2, \\ Canada
}

ABSTRACT Three hundred and one women who in their most recent pregnancy had given birth to an infant with an important congenital defect were individually matched with 301 women whose children were normal. Both cases and referents were drawn from a comprehensive survey of pregnancies in Montreal, 1982-4, and limited to women employed 30 or more hours a week until at least the 13th week of gestation. Occupational exposure to chemicals was investigated and the results classified without knowledge of case-referent status. In matched pair analysis the overall frequency of chemical exposure was higher in cases than referents (63:47), due to excesses in the cardiac and miscellaneous defect groups (ratios of 10:5 and 15:7 respectively). In analyses by nine chemical categories only exposure to aromatic solvents showed a clear excess $(18: 8 ; p \simeq 0.04)$, most evident in the urinary tract group (9:0). A comparison of cases and referents exposed to aromatic solvents showed that most of the excess was associated with toluene; the defects were varied but predominantly renal-urinary or gastrointestinal.

Case control studies in Finland have shown associations of organic solvent exposure with defects of the central nervous system ${ }^{12}$ and of oral clefts. ${ }^{3}$ Although efforts were made to avoid response bias, it could not be eliminated; these studies therefore require confirmation. In a comparison of 67 female lamination workers exposed to styrene and 67 employees in textile and food production there was no difference in the proportions of malformed children. ${ }^{4}$ A cohort of women who used styrene was linked to the Finnish Register of Congenital Malformations. The malformations observed - were fewer than expected but the numbers were small. ${ }^{5}$

Laboratory workers who are exposed to solvents and other chemicals were found in Sweden to have an increased risk of gastrointestinal atresia, although this appeared to be lower than at first thought. ${ }^{6-8}$ In a series of university laboratory employees no excess risk of congenital malformations was found in those exposed to solvents (492) compared with those not so exposed (496) ${ }^{9}$ nor was an increased risk found for children of Danish laboratory workers in a casereferent study of malformations of the gastrointestinal tract, extremities, or oral clefts. ${ }^{10}$ In the latter study there was also no increase in defects of the central nervous system in occupations where solvents

Accepted 29 September 1986 were used.

An excess of macerated stillbirths and congenital defect was observed in leatherworkers who were mainly employed in the British shoe industry. ${ }^{11}$ Among the malformations were three cases of trisomy 18 in an estimated 1200 births - a ratio of 1:400; the expected ratio was about 1:5000 births. An increased risk of stillbirth in leatherworkers, but not of fetal malformation, was later reported by our group in Canada. ${ }^{12}$ Cleft lip and palate were studied in Iowa and Michigan, two states where pesticides are widely used, ${ }^{13}$ with some evidence of an association. Potential exposure of agricultural workers and their wives to 2-4-5-T was examined in New Zealand with essentially negative results. ${ }^{14-16} \mathrm{~A}$ study of children of Australian VietNam veterans exposed to herbicides was also negative. ${ }^{17}$ After the Seveso disaster in northern Italy dioxin, which occasionally contaminates 2-4-5-T, was not incriminated as a teratogen. $^{18}$

Metals generally pass the placenta ${ }^{19}$ and so are potentially hazardous to the fetus. In female employees of a smelter in Northern Sweden exposed to lead, arsenic, and sulphur dioxide some increase in the rate of congenital malformations was reported ${ }^{20}$; it was thought unlikely that lead could have been responsible. $^{21}$ Several studies have shown a correlation between lead concentrations in children and 
mental development. In most of these the lead was probably absorbed after birth ${ }^{22}$; however, the confounding effect of socioeconomic status could not be eliminated. There is no evidence that metallic mercury is a fetal hazard but, when converted in the environment to organic forms, serious damage resulted in two major epidemics. The disease was first recognised in Japan in 1953 in an infant in Minamata City; subsequent cases in the area were traced to the consumption of fish contaminated by mercury from industrial effluent. Children and adults were affected and, in congenital cases, there was gross cerebral damage and growth retardation. ${ }^{23}$ The Japanese epidemic lasted for a long time and the situation is still under observation. In Iraq, where a large epidemic was caused by contaminated grain, the disease was similar but fewer infants were affected. ${ }^{24}$

Two chemicals-vinyl chloride monomer (VCM) in the plastics industry and hexachlorophene used by nurses for hand washing-have come under suspicion. Although some excess of congenital malformations was observed in cities with VCM plants, ${ }^{25}$ in case-control studies in West Virginia ${ }^{26}$ and Quebec ${ }^{27}$ no evidence of a hazard to the fetus was found. A report was published of malformations in children of nurses exposed to hexachlorophene ${ }^{28}$; the methodology was criticised ${ }^{29}$ and the findings not confirmed in a later study. ${ }^{30}$

\section{Montreal survey}

This scanty and largely inconclusive information on the effects of chemical exposure on fetal development, paralleled by similar ignorance regarding spontaneous abortion, stillbirth, and prematurity, led us to conduct a large survey of pregnancies in Montreal. ${ }^{31}$ During a two year period, 11 May 1982 tc 10 May 1984, 56067 women were interviewed immediately after delivery or spontaneous abortion in 11 hospitals covering some $90 \%$ of births in Montreal. Questions were asked systematically in English or French on employment and personal factors by bilingual nurse interviewers using an eight page questionnaire. Information was thus obtained for the 56067 current and 48582 past pregnancies of these women -104649 pregnancies in all. This was supplemented by detailed questions on various types of occupational exposure and on demands and conditions of work undertaken by the women during their pregnancies.

In the ascertainment of pregnancy outcome special attention was given to spontaneous abortion, stillbirth, birth weight, gestation period, and congenital defect. In current pregnancies the information was obtained from medical records and in previous pregnancies by questioning the mothers; in both the data were supplemented by further inquiries addressed to physicians and hospitals.

Results of a first analysis dealt with broad categories of adverse pregnancy outcomespontaneous abortion, stillbirth, prematurity, and congential defect - as related to full time employment in the first trimester. ${ }^{31}$ Sixty specific types of employment were considered, as defined by standard classifications of Statistics Canada. The purpose of this analysis was to put the main risks in general perspective in preparation for detailed examination of each type of adverse outcome. The volume of data from questionnaires and additional field inquiries on both work demands and various types of occupational exposure, together with the complex variety of hours and patterns of work, necessitated this phased approach.

So far as congenital defects were concerned, the preliminary report showed that of 23007 women employed at the time of their current conception and still pregnant at the 20th week, $822(3.6 \%)$ gave birth to a child with defect. The comparable figures in the previous pregnancies of 17886 women were similar, 605 (3.4\%). After allowance by logistic regression for seven confounding factors, the ratio of observed $(0)$ to expected (E) numbers of defects was increased significantly $(p<0.05)$ in service $(0 / E=1 \cdot 17)$ and manufacturing $(\mathrm{O} / \mathrm{E}=1 \cdot 14)$ sectors. Analysis of the data in 60 occupational categories showed significantly increased ratios in women employed in child care $(\mathrm{O} / \mathrm{E}=2 \cdot 19 ; \mathrm{p}<0.01)$, in certain service occupations $(\mathrm{O} / \mathrm{E}=1.54 ; \mathrm{p}<0.05)$, and in the manufacture of metal and electrical goods $(\mathrm{O} / \mathrm{E}=1 \cdot 36$; $p<0.05$ ).

In the present paper we report on the findings from a case-referent study that compared chemical exposures in the first trimester for a selected sample of women who in their current pregnancy gave birth to a malformed infant with those of similar women whose children were normal.

\section{Selection of subjects}

The case series comprised 301 women who, in their current pregnancy (that just completed at time of interview) had given birth to a live or stillborn infant considered to have an important congenital defect. Only women employed for 30 or more hours a week from time of conception until the end of the 12th week of pregnancy were included. In the series were 51 women whose pregnancy had been terminated because a fetal defect had been detected by ultrasound or amniotic fluid cytology. Spontaneous abortions of a defective fetus before the 20th week of pregnancy were not included. Among the 301 pregnancies were six in which the defect was present in one of twins and 
one in which both twins were affected. Infants with defects considered minor, of genetic aetiology, or unlikely to be caused by chemical exposure in early pregnancy disqualified the mothers from case or referent series. On this basis minor defects such as birth marks and skin tags, together with congenital dislocations, club foot, hernias, and undescended testes were excluded. All serious cases of hypospadias were included but only a $50 \%$ systematic sample of the more numerous cases of minor degree. Cases excluded as of genetic origin were mainly of polydactyly or syndactyly. The distribution of the 301 cases finally selected is shown in table 1 by diagnostic category.

The referent (control) series was also drawn from women employed for 30 or more hours a week for the first 12 weeks of pregnancy from women whose infants were considered normal. For each case, a referent was selected from the same hospital matched so far as possible for gravidity, educational level, (primary, secondary, college, or university), maternal age (plus or minus 1 year), and date of delivery. An exact match was not always achieved but the distributions of these variables in cases and referents were closely similar (see table 1).

Table 1 Analysis of case-referent pairs by matching variables and estimated severity of chemical exposure

\begin{tabular}{|c|c|c|c|c|c|c|c|c|c|}
\hline \multirow[t]{3}{*}{ Type of defect and No of cases } & \multicolumn{3}{|c|}{ Mean value of matching variables* } & \multicolumn{6}{|c|}{ Chemical exposure grade } \\
\hline & \multirow[t]{2}{*}{ Age (y) } & \multirow[t]{2}{*}{ Gravidity } & \multirow[t]{2}{*}{ Education $\dagger$} & \multicolumn{3}{|c|}{ All grades } & \multicolumn{3}{|c|}{ Moderate or severe } \\
\hline & & & & $\begin{array}{l}\text { Case } \\
\text { only }\end{array}$ & $\begin{array}{l}\text { Referent } \\
\text { only }\end{array}$ & Both & $\begin{array}{l}\text { Case } \\
\text { only }\end{array}$ & $\begin{array}{l}\text { Referent } \\
\text { only }\end{array}$ & Both \\
\hline $\begin{array}{l}\text { Central nervous system: } \\
\text { Anencephaly (27) } \\
\text { Spina bifida (28) } \\
\text { Hydrocephaly (4) } \\
\text { Microcephaly (2) }\end{array}$ & $\begin{array}{l}27 \cdot 11(+0 \cdot 15) \\
27.75(+0 \cdot 07) \\
28 \cdot 25 \\
27 \cdot 00\end{array}$ & $\begin{array}{l}1.52 \\
1.82 \\
1.25 \\
1.50\end{array}$ & $\begin{array}{l}2 \cdot 26(+0.04) \\
2 \cdot 29(+0.21) \\
2 \cdot 50(-0.25) \\
2 \cdot 00\end{array}$ & $\begin{array}{r}3 \\
6 \\
1 \\
1 \\
11\end{array}$ & $\begin{array}{r}5 \\
5 \\
- \\
- \\
10\end{array}$ & $\begin{array}{l}-4 \\
1 \\
1\end{array}$ & $\begin{array}{l}1 \\
2 \\
1 \\
1 \\
5\end{array}$ & $\begin{array}{r}2 \\
3 \\
1 \\
- \\
6\end{array}$ & $\begin{array}{l}- \\
-\end{array}$ \\
\hline Cleft lip or palate (20) & $25 \cdot 85$ & $1 \cdot 55$ & $2 \cdot 25(-0.05)$ & 4 & 3 & 3 & 2 & 1 & - \\
\hline $\begin{array}{l}\text { Cardiac group: } \\
\text { Transposed great vessels (6) } \\
\text { Left heart hypoplasia (4) } \\
\text { Pulmonary atresia/stenosis (4) } \\
\text { Coarctation of aorta (6) } \\
\text { Fallot's tetralogy (7) } \\
\text { Other single defect (14) } \\
\text { Multiple defects (8) }\end{array}$ & $\begin{array}{l}25 \cdot 17 \\
27 \cdot 50 \\
28 \cdot 00(+0 \cdot 75) \\
29 \cdot 67 \\
27 \cdot 71 \\
28.07(-0.5) \\
28.63\end{array}$ & $\begin{array}{l}2.00(-0.17) \\
2.00 \\
1.75 \\
2.00 \\
1.14 \\
1.86(-0.07) \\
1.38\end{array}$ & $\begin{array}{l}2.67(-0.17) \\
2.50 \\
2.25(-0.25) \\
2.33(-0.16) \\
2 \cdot 29(+0 \cdot 14) \\
2.29(+0 \cdot 14) \\
2.50\end{array}$ & $\begin{array}{l}\frac{2}{1} \\
4 \\
\frac{1}{2} \\
10\end{array}$ & $\begin{array}{l}\frac{1}{1} \\
\frac{1}{1} \\
\frac{1}{5}\end{array}$ & $\frac{-}{\frac{-}{2}}$ & $\begin{array}{l}-1 \\
\frac{1}{3} \\
\frac{1}{-} \\
6\end{array}$ & $\begin{array}{l}- \\
\frac{1}{2} \\
\frac{1}{4}\end{array}$ & $\begin{array}{l}E \\
= \\
= \\
=\end{array}$ \\
\hline $\begin{array}{l}\text { Gastrointestinal group: } \\
\text { Tracheo-oesophageal fistula (4) } \\
\text { Intestinal atresia (4) } \\
\text { Anal atresia/stenosis (8) } \\
\text { Omphalocele/gastroschisis (11) } \\
\text {-Diaphragmatic hernia (5) }\end{array}$ & $\begin{array}{l}27 \cdot 75 \\
28 \cdot 50 \\
27 \cdot 38 \\
22 \cdot 45(+0 \cdot 01) \\
25 \cdot 20 \cdot(+0 \cdot 2)\end{array}$ & $\begin{array}{l}2 \cdot 50(-0 \cdot 25) \\
2.00 \\
1.50 \\
1.09 \\
1.40\end{array}$ & $\begin{array}{l}2 \cdot 50 \\
2 \cdot 00(+0 \cdot 25) \\
2 \cdot 38 \\
2 \cdot 18(+0 \cdot 09) \\
2 \cdot 60(-0 \cdot 20)\end{array}$ & $\begin{array}{l}\frac{2}{1} \\
\frac{1}{2} \\
\frac{6}{6}\end{array}$ & $\begin{array}{l}\overline{-} \\
\frac{2}{2} \\
\frac{2}{6}\end{array}$ & $\frac{1}{1}$ & $\frac{1}{\frac{1}{3}}$ & $\begin{array}{l}- \\
\frac{2}{2} \\
\frac{1}{5}\end{array}$ & $\begin{array}{l}\overline{1} \\
\overline{-}\end{array}$ \\
\hline $\begin{array}{l}\text { Rênal-urinary group: } \\
\text { Hypospadias (51) } \\
\text { Hydronephrosis (15) } \\
\text { Polycystic kidney (5) } \\
\text { Renal agenesis/dysplasia (8) }\end{array}$ & $\begin{array}{l}25 \cdot 96 \\
27 \cdot 20 \\
26 \cdot 40 \\
27 \cdot 75(-0 \cdot 12)\end{array}$ & $\begin{array}{l}1 \cdot 26 \\
1.47 \\
1.20 \\
1.63\end{array}$ & $\begin{array}{l}2.51(-0.02) \\
2.53(-0.06) \\
2.60 \\
2.50(-0.25)\end{array}$ & $\begin{array}{r}11 \\
3 \\
\frac{3}{17}\end{array}$ & $\begin{array}{r}12 \\
2 \\
2 \\
- \\
16\end{array}$ & $\frac{5}{1}$ & $\begin{array}{l}\frac{4}{-} \\
\overline{4} \\
\frac{4}{4}\end{array}$ & $\begin{array}{l}4 \\
1 \\
1 \\
1 \\
\frac{1}{7}\end{array}$ & $\begin{array}{l}1 \\
- \\
-\end{array}$ \\
\hline $\begin{array}{l}\text { Miscellaneous: } \\
\text { Cataract (1) } \\
\text { Limb deformities (9) } \\
\text { Multiple defects (41) } \\
\text { Trisomy (excl Down's) (9) }\end{array}$ & $\begin{array}{l}25 \cdot 00 \\
26 \cdot 00 \\
28 \cdot 29(+0 \cdot 29) \\
31 \cdot 33(-0 \cdot 44)\end{array}$ & $\begin{array}{l}1 \cdot 00 \\
1 \cdot 11 \\
1 \cdot 83 \\
2 \cdot 11\end{array}$ & $\begin{array}{l}2.00 \\
2 \cdot 56(-0 \cdot 12) \\
2.42(-0.03) \\
2.44\end{array}$ & $\begin{array}{r}1 \\
4 \\
9 \\
1 \\
15\end{array}$ & $\begin{array}{l}-1 \\
5 \\
1 \\
7\end{array}$ & $\overline{-}$ & $\begin{array}{r}1 \\
1 \\
2 \\
1 \\
5\end{array}$ & $\begin{array}{l}\frac{-}{2} \\
\frac{2}{2}\end{array}$ & $\begin{array}{l}- \\
- \\
-\end{array}$ \\
\hline Total $(301)$ & & & & 63 & 47 & 32 & 25 & 25 & 2 \\
\hline
\end{tabular}

*Where these are not identical, the deviation of referents from cases is shown in parentheses.

†Educational level reached: primary $=1$; secondary $=2$; college/university $=3$. 


\section{Field inquiry}

The histories of employment in the current pregnancy of the 602 women selected for study were photocopied from the questionnaires and passed to two of us (JL and $\mathrm{RC}$-occupational hygienists), unidentified as to case or referent status. The records were then divided into two groups according to the Standard Industrial Classification (SIC), ${ }^{32}$ as used in the Canadian census. In the first group were included jobs in which we thought chemical exposure could have occurred. These included work in manufacturing (SIC 01-39), wholesale and retail trades (SIC 51-2, 55-60, 63), hospitals and services (SIC 86, 91-9), and certain types of teaching and research in the arts and sciences (SIC 85 ). In the second group were all other occupationsthat is, those in which chemical exposure seemed improbable. These included clerical, administrative work in communications and public services (SIC 48-9), construction and transport (SIC 40-7), commerce (SIC 53-4, 61-2, 64-5), finances, insurance, real estate and business (SIC 70-7), government services (SIC 81-4), and other types of work in teaching and research (SIC 85).

In the first group information about possible exposures was usually obtained by visits from JL or RC to the workplace. In the second group information was obtained by telephone from the employer or other appropriate person. Each case-referent pair was numbered in sequence and code letters A or B assigned to case or referent in random order. The pairs were then divided between the two hygienists, kept blind as to code, odd numbered pairs to JL and even to RC. Field inquiries were made by visit or telephone according to plan or, if outside greater Montreal, in whatever way seemed most efficient. JL and RC systematically discussed their findings in various employment situations to improve and standardise the quality of the information obtained.

After recording the products to which the women were exposed at work, chemical compositions were determined where necessary by correspondence with the manufacturers. Two parameters of severity were estimated for each exposure ( $a$ ) average intensity during the period of use and $(b)$ maximal intensity reached. Both parameters were separately graded as light, moderate, or heavy. This was a subjective judgment using agreed guidelines: "slight" implied that the exposure though known to be present was not readily detectable, "moderate" that it was readily detectable but at levels below any control limit, and "strong" present at levels that caused discomfort. In addition, the estimated duration of maximal exposure per week was recorded. These quantitative assessments of exposure proved difficult to make and have limited validity.
For the purpose of analysis all chemical exposures recorded for any case or referent were listed alphabetically and classified in consultation with an experienced toxicologist into nine categories: aliphatic solvents, aromatic solvents, plasticisers and plastics, metals (including fume), oils, detergents, gases, a combined group of bactericides, fungicides and pesticides, and a miscellaneous remainder. Inevitable problems in classification were resolved without knowledge of pregnancy outcome. The miscellaneous group largely comprised acids, bases, surface irritants, and substances that, in the opinion of our toxicological adviser, were unlikely to be absorbed or to have fetotoxic potential.

Of the 602 women investigated, $428(71 \%)$ had no chemical exposure of any sort; the remaining 174 women were exposed to one or more of 260 identifiable chemicals or compounds, 256 of which were allocated to one of the nine categories and four to two categories. Three quarters $(74 \%)$ of the 174 women were exposed to more than one chemical, 63 $(37 \%)$ from two to five, $36(21 \%)$ from six to ten, and $28(16 \%) 11$ or more. The proportion of cases exposed $(32 \%)$ was slightly higher than of referents $(26 \%)$, mainly due to an excess of single exposures $(30 \mathrm{com}$ pared with 15). The proportion of women with multiple exposures was similar in the two groups (cases $22 \%$; referents $18 \%$ ).

\section{Results}

The data were analysed in case-referent pairs by type of malformation and type of exposure in terms of intensity and nature. Each pair was first examined for any recorded chemical exposure and classified as concordant or discordant in three grades of severity. This analysis, shown in table 1 , indicates that there were few differences in the distribution of moderate or severe exposures for specific defects and their referents but rather more differences when exposures of all grades were considered. Two groups of defects had an excess of cases only exposed compared with referents only: cardiac (10:5) and miscellaneous (15:7). Within the cardiac group some evidence of inequality (4:0) is seen with the seven cases of Fallot's tetralogy. The four exposures in question had little in common: three of moderate severity included chemicals used in printing (acetic acid, hydroquinone, ammonium thiocyanate), soldering (toluene, turpentine, pine resin fume), and nursing (isopropanol, chlorhexidine, gluconate); the light exposure was to detergents used in a snack bar. In the miscellaneous group were four limb deformities in which the mother was exposed compared with one referent (4:1). In all four exposed cases cleansing agents were used-three containing sodium hypochlorite; in only one was the exposure of 
moderate degree. Among the cases of multiple defect no particular chemical agent appeared to be responsible for the excess $(9: 5)$.

An analysis is presented in table 2 by the nine chemical categories without regard for severity of exposure. The pairs in which both case and referent were exposed are shown separately to indicate the overall frequency of contact with the various materials. Except for the aromatic solvents (case-referent ratio 18:8), the differences appear small and unimportant; most of the difference is concentrated within renalurinary defects (ratio 9:0). In this group six of the nine exposures were to toluene, together with xylene in one and isophorone and an aromatic solvent (type unspecified) in another; two of the three other exposures were to benzyl alcohol and B phenoxy ethanol and one to styrene and aromatic solvent (type unspecified).

Details of the 19 cases and nine referents exposed to aromatic solvents (including the one concordant pair) are set out in table 3. The difference between the two series is almost wholly in respect of toluene (11:3) with perhaps some excess of aromatic solvent (type unspecified) (7:4). The defects associated with the latter two solvents were varied: renal-urinary (7), gastrointestinal (4), cardiac (2), spina bifida (2), and cataract (1). Most of the exposures were in manufacturing jobs.

\section{Discussion}

Of the nine groups into which individual chemical exposures were classfied, only aromatic solvents showed a suspicious excess of cases. As this was not examined as a prior hypothesis (although it might have been because of previous reports, see above), its statistical significance $(Z=1.77$; one sided $p \simeq 0.04)$ in the McNemar test ${ }^{33}$ may be an overestimate. In previous reports 2373435 solvent exposure of various types has been associated with increased risk of de-

Table 2 Analysis of case-referent pairs by type of chemical exposure: all grades of severity. (Group subtotals in parentheses)

\begin{tabular}{|c|c|c|c|c|c|c|c|c|c|c|c|c|c|c|c|c|c|c|}
\hline $\begin{array}{l}\text { Tvpe of defect } \\
\text { Case/referent } \\
\text { Central nervous system: }\end{array}$ & \multicolumn{2}{|c|}{$\begin{array}{l}\text { Aliphatic } \\
\text { solvents } \\
+1--1+\end{array}$} & \multicolumn{2}{|c|}{$\begin{array}{l}\text { Aromatic } \\
\text { solvents } \\
+/--1+\end{array}$} & \multicolumn{2}{|c|}{$\begin{array}{l}\text { Plasticisers } \\
\text { etc. } \\
+/--1+\end{array}$} & \multicolumn{2}{|c|}{$\begin{array}{l}\text { Metals } \\
\text { (incl fume) } \\
+/--I+\end{array}$} & \multicolumn{2}{|c|}{$\begin{array}{l}\text { Oils } \\
+1--1+\end{array}$} & \multicolumn{2}{|c|}{$\begin{array}{l}\text { Bactericides/ } \\
\text { pesticides etc. } \\
+/--1+\end{array}$} & \multicolumn{2}{|c|}{$\begin{array}{l}\text { Detergents } \\
+1--1+\end{array}$} & \multicolumn{2}{|c|}{$\begin{array}{l}\text { Gases } \\
+1--1+\end{array}$} & \multicolumn{2}{|c|}{$\begin{array}{l}\text { Miscellaneous } \\
+1--1+\end{array}$} \\
\hline $\begin{array}{l}\text { Central nervous system: } \\
\text { Anencephaly } \\
\text { Spina bifida } \\
\text { Hydrocephaly } \\
\text { Microcephaly }\end{array}$ & $\begin{array}{r}1 \\
5 \\
1 \\
(7)\end{array}$ & $\begin{array}{l}4 \\
4 \\
1 \\
(9)\end{array}$ & (2) & $\begin{array}{l}1 \\
2\end{array}$ & $\begin{array}{l}1 \\
3\end{array}$ & (1) & $\begin{array}{l}1 \\
1 \\
1\end{array}$ & $\begin{array}{l}2 \\
1 \\
1 \\
1 \\
(5)\end{array}$ & (1) & $\begin{array}{l}2 \\
1\end{array}$ & $\begin{array}{l}1 \\
3\end{array}$ & $\begin{array}{l}3 \\
3\end{array}$ & $\begin{array}{r}1 \\
1 \\
(2)\end{array}$ & $\begin{array}{l}4 \\
3\end{array}$ & $\begin{array}{c}2 \\
2 \\
1 \\
(5)\end{array}$ & (1) & $\begin{array}{c}2 \\
1 \\
1 \\
(4)\end{array}$ & $\begin{array}{r}1 \\
4 \\
1 \\
(6)\end{array}$ \\
\hline Cleft lip/palate & (3) & (3) & (0) & (0) & (2) & (3) & (2) & (1) & (2) & (2) & (2) & (2) & (2) & (2) & (0) & (1) & (3) & (4) \\
\hline $\begin{array}{l}\text { Cardiac group: } \\
\text { Transposed great vessels } \\
\text { Left heart hypoplasia } \\
\text { Pulmonary atresia/stenosis } \\
\text { Coarctation of aorta } \\
\text { Fallots tetralogy } \\
\text { Other single defects } \\
\text { Multiple defects }\end{array}$ & $\begin{array}{c}1 \\
2 \\
2 \\
1 \\
1 \\
(7)\end{array}$ & $\begin{array}{c}1 \\
1 \\
2 \\
(4)\end{array}$ & $\begin{array}{l}1 \\
1 \\
1 \\
(3)\end{array}$ & $\begin{array}{c}1 \\
(2)\end{array}$ & $\begin{array}{l}1 \\
1 \\
1 \\
(3)\end{array}$ & $\begin{array}{r}1 \\
(2)\end{array}$ & 1 & $\begin{array}{l}1 \\
(2)\end{array}$ & $\begin{array}{c}1 \\
1 \\
(2)\end{array}$ & $\begin{array}{c}1 \\
2 \\
(4)\end{array}$ & $\begin{array}{l}1 \\
1 \\
(2)\end{array}$ & $\begin{array}{c}1 \\
(2)\end{array}$ & $\begin{array}{l}1 \\
2 \\
1 \\
(5)\end{array}$ & $\begin{array}{c}1 \\
2 \\
1 \\
(4)\end{array}$ & $\begin{array}{c}1 \\
1 \\
(2)\end{array}$ & $\begin{array}{l}1 \\
1 \\
(2)\end{array}$ & $\begin{array}{c}1 \\
3 \\
1 \\
1 \\
(7)\end{array}$ & $\begin{array}{r}1 \\
1 \\
(3)\end{array}$ \\
\hline $\begin{array}{l}\text { Gastrointestinal group: } \\
\text { Tracheo-oesophageal } \\
\text { fistula } \\
\text { Intestinal atresia } \\
\text { Anal atresia } \\
\text { Omphalocele } \\
\text { Diaphragmatic hernia }\end{array}$ & $\begin{array}{l}1 \\
1 \\
2 \\
(4)\end{array}$ & $\begin{array}{l}1 \\
3 \\
2 \\
(6)\end{array}$ & $\begin{array}{l}2 \\
1 \\
(3)\end{array}$ & $\begin{array}{c}2 \\
(2)\end{array}$ & (0) & $\begin{array}{l}1 \\
1 \\
(2)\end{array}$ & (1) & (1) & (2) & $\begin{array}{l}1 \\
1 \\
3 \\
1 \\
(6)\end{array}$ & (2) & $\begin{array}{r}1 \\
1 \\
2 \\
(4)\end{array}$ & $\begin{array}{r}1 \\
1 \\
(2)\end{array}$ & $\begin{array}{l}2 \\
3 \\
1 \\
(6)\end{array}$ & (1) & (0) & $\begin{array}{l}2 \\
(4)\end{array}$ & $\begin{array}{c}2 \\
2 \\
1 \\
(5)\end{array}$ \\
\hline $\begin{array}{l}\text { Renal-urinary group: } \\
\text { Hypospadias } \\
\text { Hydronephrosis } \\
\text { Polycystic kidney } \\
\text { Renal agenesis }\end{array}$ & $\begin{array}{c}6 \\
1 \\
3 \\
(10)\end{array}$ & $\begin{array}{r}12 \\
2 \\
2 \\
1 \\
(17)\end{array}$ & $\begin{array}{l}6 \\
1 \\
2 \\
(9)\end{array}$ & (0) & $\begin{array}{l}5 \\
1\end{array}$ & $\begin{array}{c}3 \\
2 \\
1 \\
2 \\
(8)\end{array}$ & $\begin{array}{l}3 \\
2\end{array}$ & $\begin{array}{r}1 \\
1 \\
(2)\end{array}$ & $\underset{(5)}{2}$ & $\begin{array}{c}3 \\
2 \\
1 \\
1 \\
\text { (7) }\end{array}$ & $\begin{array}{c}1 \\
(5)\end{array}$ & $\begin{array}{r}3 \\
1 \\
2 \\
(6)\end{array}$ & $\begin{array}{c}2 \\
(9)\end{array}$ & $\begin{array}{r}7 \\
2 \\
1 \\
(10)\end{array}$ & (1) & $\begin{array}{l}2 \\
1 \\
1 \\
1 \\
(5)\end{array}$ & $\begin{array}{c}7 \\
1 \\
2 \\
(10)\end{array}$ & $\begin{array}{r}9 \\
1 \\
2 \\
(12)\end{array}$ \\
\hline $\begin{array}{l}\text { Miscellaneous: } \\
\text { Cataract } \\
\text { Limb deformities } \\
\text { Multiple defects } \\
\text { Trisomy (excl 21) }\end{array}$ & $\begin{array}{c}1 \\
1 \\
8 \\
1 \\
(11)\end{array}$ & $\begin{array}{l}5 \\
(5)\end{array}$ & (1) & $\begin{array}{l}1 \\
(1)\end{array}$ & $\begin{array}{c}1 \\
1 \\
1 \\
(3)\end{array}$ & $\begin{array}{l}1 \\
(1)\end{array}$ & (2) & $\begin{array}{l}2 \\
(2)\end{array}$ & $\begin{array}{r}1 \\
3 \\
(4)\end{array}$ & $\begin{array}{c}1 \\
1 \\
(2)\end{array}$ & $\begin{array}{r}4 \\
3 \\
(7)\end{array}$ & $\begin{array}{r}1 \\
1 \\
(2)\end{array}$ & $\begin{array}{c}1 \\
5 \\
(6)\end{array}$ & $\begin{array}{c}2 \\
2 \\
(4)\end{array}$ & (2) & $\begin{array}{l}1 \\
(1)\end{array}$ & $\begin{array}{r}1 \\
2 \\
4 \\
(7)\end{array}$ & $\begin{array}{l}3 \\
(3)\end{array}$ \\
\hline Total discordant & 42 & 44 & 18 & 8 & 18 & 17 & 16 & 13 & 16 & 24 & 22 & 22 & 26 & 33 & 11 & 10 & 35 & 33 \\
\hline Total concordant $+1-$ & 17 & 198 & 1 & 274 & 5 & 259 & 2 & 270 & 2 & 269 & 6 & 251 & 3 & 239 & 0 & 280 & 8 & 225 \\
\hline
\end{tabular}


Table 3 Occupation and aromatic solvent exposure in 19 cases and nine referents from one concordant and 26 discordant pairs

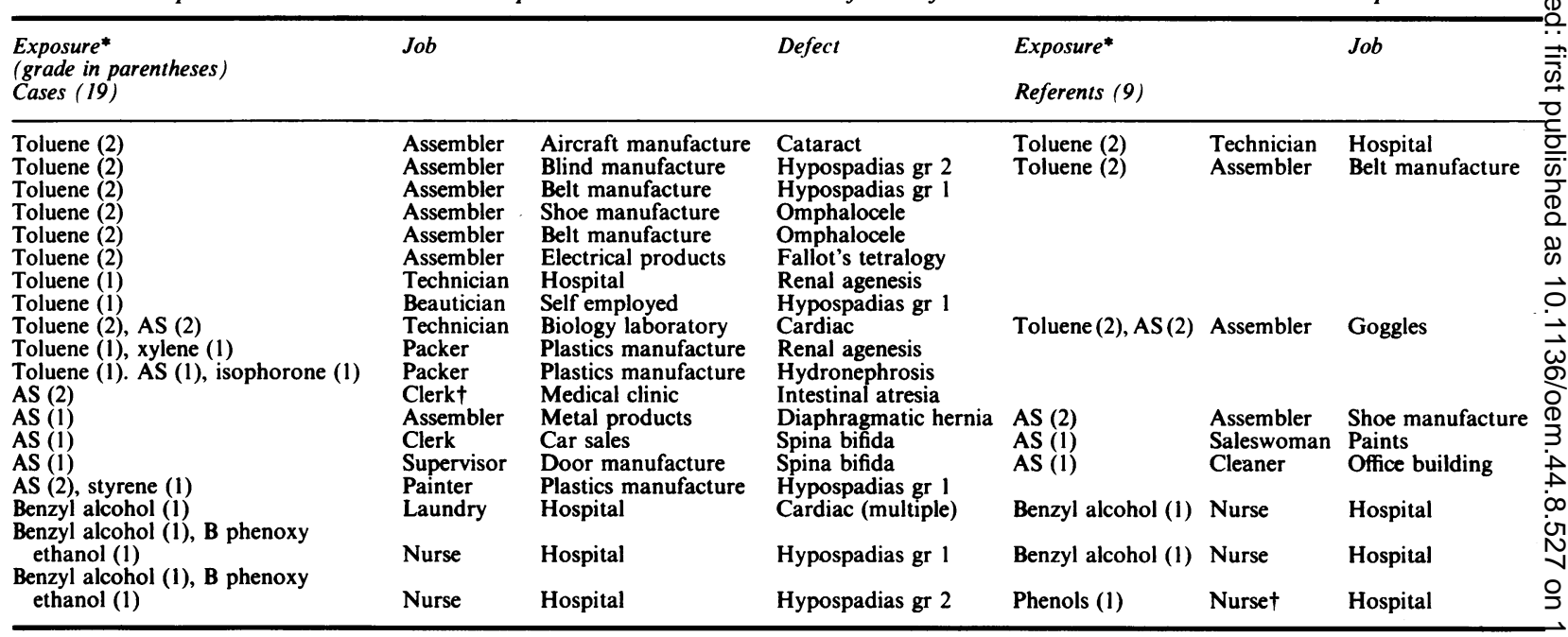

*Aromatic solvent (AS)-type unspecified.

+Concordant pair.

fects of the central nervous system, oral clefts, gastrointestinal atresia, and sacral agenesis. In some of these studies there was the possibility of response bias whereas our data on exposure were collected and coded without knowledge of outcome.

Our results throw most suspicion on toluene and to a lesser extent on aromatic solvent, type unspecified, which commonly contains toluene. The associated anomalies, although predominantly renal-urinary and gastrointestinal, were quite heterogeneous and the reported exposures were not impressive. Organic solvents cross the placenta ${ }^{36}$ however, and concern has been expressed that toluene, increasingly used as a substitute for benzene, is embryotoxic. ${ }^{37}$ The exposures were probably low but there is evidence that toluene may be taken up and accumulated in fatty tissue better than most other solvents. ${ }^{38}$ Three cases reported by Hersh et al describe a variety of central nervous system, craniofacial, and limb anomalies in children born to women who inhaled (sniffed) large quantities of pure toluene in pregnancy. ${ }^{39}$ Two of these three children had also urinary tract abnormalities similar to those observed in our study.

Overall, our data suggest that in Montrealperhaps in North America generally-some 30\% of pregnant women have some occupational exposure to chemical substances, usually at a low level. In this study only women without a major change in occupation before the 13th week of pregnancy were included; others may have left work earlier or been reassigned to a job without chemical exposure. Paternal exposure will be examined later.
The collaboration of the staff in the 11 maternity units (Charles Lemoyne, Jewish General, Laval, Maisonneuve-Rosemont, Notre-Dame, Sacré-Coeur, Ste-Justine, Ste-Luc, Royal Victoria, St Mary's, StMichel) is gratefully acknowledged. Drs C Commandeur and I Tsarevsky investigated and coded the birth defects. Professor D Ecobichon and F Labreche helped in the classification of the chemical exposures.

\section{References}

1 Holmberg PC. CNS defects in children born to mothers exposed to organic solvents during pregnancy. Lancet 1979;ii:177-9.

2 Holmberg PC, Nurminen M. Congenital defects of CNS and occupational factors during pregnancy. A case-referent study. Am J Ind Med 1980;1:167-76.

3 Holmberg PC, Hernberg S, Kurppa K, Riala R, Rantala K. Oral clefts and organic solvent exposure during pregnancy. Int Arch Occup Environ Health 1982;50:371-6.

4 Harkonen H, Holmberg PC. Obstetric histories of women occupationally exposed to styrene. Scand J Work Environ Health 1982;8:74-7.

5 Harkonen H, Tola S, Korkala ML, Hernberg S. Congenital malformations, mortality and styrene exposure. Ann Acad Med 1984;13:404-7.

6 Meirik O, Källén B, Gauffin U, Ericson A. Major malformations in infants born of women who worked in laboratories while pregnant. Lancet 1979;ii:91.

7 Ericson A, Pol M, Källén B, Meirik O, Westerholm P. Gastrointestinal atresia and maternal occupation during pregnancy. $J$ Occup Med 1982;27:515-8.

8 Ericson A, Källén B, Zetterstrom R, Eriksson M, Westerholm P. Delivery outcome of women working in laboratories during pregnancy. Arch Environ Health 1984;39:5-10.

9 Axelsson O, Edling C, Andersson L. Pregnancy outcome among women in a Swedish rubber plant. Scand $J$ Work Environ Health 1983;9:79-83. 
10 Olsen J. Risk of exposure to teratogens among laboratory staff and patients. Dan Med Bull 1983;30:24-8.

11 Clarke MC, Mason ES. Leatherwork: a possible hazard to reproduction. Br Med J 1985;290:1235-7.

12 McDonald AD, McDonald JC. Outcome of pregnancy in leatherworkers. Br Med J 1986;292:979-81.

13 Gordon JE, Shy CM. Agricultural chemical use and congenital cleft lip and/or palate. Arch Environ Health 1981;36:213-21.

14 Hanify JA, Metcalf P, Nobbs CL, Worsley KJ. A serial spraying of 2-4-5-T and human birth malformation: an epidemiological investigation. Science 1981;212:349-51.

15 Smith AH, Fisher DO, Pearce N, Chapman CJ. Congenital defects and miscarriages among New Zealand 2-4-5-T sprayers. Arch Environ Health 1982;37:197-200.

16 Roan CC, Matanoski GE, McIlnay CQ, et al. Spontaneous abortions, stillbirth and birth defects in families of agricultural pilots. Arch Environ Health 1984;39:57-60.

17 Lipson A, Pearn J, Barr B. Herbicides and teratogenesis. Med J Aust 1983;2:367-8.

18 Tuchmann-Duplessis H. Seveso, prédictions et réalité. Bull Acad Natl Med 1982;166:1001-8.

19 Tsuchiya H, Mitani K, Kodama K, Nakata T. Placental transfer of heavy metals in normal pregnant Japanese women. Arch Environ Health 1984;39:11-7.

20 Nordstrom S, Beckman L, Nordenson I. Occupational and environmental risks around a smelter in northern Sweden. VI Congenital malformations. Hereditas 1979;90:297-302.

21 Kalter H, Warkany J. Congenital malformations: etiologic factors and their role in prevention. $N$ Engl $J$ Med 1983; 308:424-31, 491-7.

22 Gloag $\mathrm{D}$. Is low-level lead pollution dangerous? $\mathrm{Br}$ Med $\mathrm{J}$ 1980;281:1622-5.

23 Tsubaki T, Irukayama K, eds. Minimata disease: methylmercury poisoning in Minamata and Niigata, Japan. Amsterdam: Elsevier, 1977.

24 Amin-Zaki L, Majeed MA, Elhassani SB, Clarkson TW, Greenwood MR, Doherty RA. Prenatal methylmercury poisoning: chemical observations over 5 years. Am $J$ Dis Child 1979;133:172-7.

25 Infante PF. Oncogenic and mutagenic risks in communities with polyvinyl chloride production facilities. Ann NY Acad Sci 1976;271:49-57.

26 Edmonds L, Anderson CE, Flynt JW, James LM. Congenital central nervous system malformations and vinyl chloride monomer exposure: a community study. Teratology 1978;17:137-42.

27 Thériault G, Iturra H, Gingras S. Evaluation of the association between birth defects and exposure to ambient vinyl chloride. Teratology 1983;27:359-70.

28 Halling $H$. Suspected link between exposure to hexachlorophene and birth of malformed infants. Lakartidningen 1977;74: 765-76. (Swedish text.)

29 Källén B. Hexachlorophene teratogenicity in humans disputed. JAMA 1978;240:1585-6.

30 Baltzar B, Ericson A, Kallén B. Delivery outcome in women employed in medical occupations in Sweden. $J$ Occup Med 1979;21;543-8.

31 McDonald AD, McDonald JC, Armstrong B, et al. Occupation and pregnancy outcome. Br J Ind Med 1987;44:521-6.

32 Standard industrial classification. Ottawa: Statistics Canada, 1980.

33 Breslow NE, Day NE. Statistical methods in cancer research. The analysis of case-control studies. Lyon: International Agency for Research on Cancer, 1980.

34 Blomqvist U, Ericson A, Kallén B, Westerholm P. Delivery outcome for women working in the pulp and paper industry. Scand J Work Environ Health 1981;7:114-8.

35 Kucera J. Exposure to fat solvents. A possible cause of sacral agenesis in man. $J$ Pediatr 1986;72:857-9.

36 Wilson JG. Environmental chemicals. In: Wilson JG, Fraser FC, eds. Handbook of teratology. New York: Plenum Press, 1977:357-85.

37 Fishbein L. An overview of environmental and toxicological aspects of aromatic hydrocarbons. II. Toluene. Sci Total Environ 1985;42:267-88.

38 Astrand I. Uptake of solvents in the blood and tissues of man. A review. Scand J Work Eiviron health 1975;1;199-218.

39 Hersh JH, Podruch PE, Rogers G, Weisskopf B. Toluene embryopathy. J Pediatr 1985;106:922-7.

\section{Destruction of manuscripts}

From 1 July 1985 articles submitted for publication will not be returned. Authors whose papers are rejected will be advised of the decision and the manuscripts will be kept under security for three months to deal with any inquiries and then destroyed. 